\title{
OPINI NELAYAN TENTANG AKSES INFORMASI PUBLIK
}

\author{
C.Suprapti Dwi Takariani \\ Balai Pengkajian dan Pengembangan Komunikasi dan Informatika Bandung (BPPKI) Bandung, Jl.Pajajaran No.88 \\ Bandung-40173, Jawa Barat, Telp.022-6017493,Fax.022-6021740. HP.081220179515. Email: \\ dwi.takariani@gmail.com \\ Naskah diterima tanggal 30 September 2015, direvisi tanggal 6 November 2015, disetujui tanggal 11 November \\ 2015
}

\section{FISHERMEN'S OPINION ON PUBLIC INFORMATION ACCESS}

\begin{abstract}
Fishermen are one of the communities who cling their life on fishing. Currently there are many poor fishermen in Indonesia. One of the causes of their poverty is a lack of access to information and education for the fishermen. Thereby, this study was focused on describing to what extent does the fishermen opinion regarding their access to public information? The purpose of this study is to analyze the fishermen opinion on public information access. In collecting the data, fishermen from Karawang regency were selected as the population and the location sampling at the district level was conducted by simple random sampling. Then, a proportional sampling were conducted to select the respondents in each district. Furthermore, the overall sample size is determined based on the Tarro Yamane formula. The results of the study show that the respondent access to public information was depended on interpersonal media.The respondents had a positive opinion towards the access to public information in sense of confidence indicators, assessment indicators, and the indicators of behavioral tendencies.
\end{abstract}

Keywords:opinion, fishermen, access, public information.

\begin{abstract}
Abstrak
Nelayan merupakan salah satu komunitas yang menggantungkan kehidupannya dari mencari ikan di laut. Saat ini masih banyak nelayan Indonesia yang miskin. Rendahnya akses informasi dan pendidikan nelayan menjadi salah satu penyebab kemiskinan tersebut. Permasalahan yang diangkat dalam penelitian ini adalah sejauhmana opini nelayan tentang akses informasi publik?. Tujuan penelitian ini adalah ingin menganalisis opini nelayan tentang akses informasi publik. Populasi penelitian adalah nelayan di Kabupaten Karawang, pengambilan sampel lokasi di tingkat kecamatan dilakukan dengan cara acak sederhana, pengambilan sampel responden untuk tiap kecamatan dilakukan secara proportional sampling, jumlah sampel secara menyeluruh ditetapkan berdasarkan rumus Tarro Yamane. Hasil penelitian menunjukkan akses responden terhadap informasi publik tergantung pada media interpersonal. Opini responden tentang akses informasi publik terhadap media interpersonal pada dimensi keyakinan, dimensi penilaian ,dan dimensi kecenderungan perilaku pada umumnya adalah positif.
\end{abstract}

Kata kunci: opini, nelayan, akses, informasi publik 


\section{PENDAHULUAN}

Pemerintah saat ini juga ingin mengembalikan Indonesia sebagai negara maritim yang tangguh dengan menekankan pembangunan pada sektor maritim. Sektor ini juga memunyai potensi yang cukup besar dalam mengembangkan perekonomian suatu bangsa dan akan menyerap tenaga kerja yang cukup besar (Sutisna, 2012). Data dari Badan Pusat Statistik (2013) sekitar 35\% dari jumlah tenaga kerja akan terserap pada sektor kelautan. Potensi ekonomi dari sektor maritim khususnya sektor perikanan hingga saat ini juga belum dimanfaatkan secara produktif dan optimal, dan hasilnya juga belum bisa dinikmati secara merata khususnya oleh nelayan di berbagai wilayah di Indonesia, sehingga belum memberikan manfaat secara ekonomi bagi masyarakat khususnya masyarakat nelayan.

Secara geografis masyarakat nelayan adalah masyarakat yang hidup, tumbuh, dan berkembang di kawasan pesisir, yakni suatu kawasan transisi antara wilayah darat dan laut. Mereka memiliki sistem nilai dan simbol-simbol kebudayaan sebagai referensi perilaku-perilaku mereka sehari-hari. Faktor budaya ini menjadi pembeda masyarakat nelayan dari kelompok masyarakat lainnya (Sipahelut, 2010). Sebagian besar masyarakat pesisir, baik langsung maupun tidak langsung, menggantungkan kelangsungan hidupnya dari mengelola potensi sumberdaya perikanan, mereka menjadi komponen utama konstruksi masyarakat maritim Indonesia. Kabupaten Karawang merupakan salah satu daerah yang terletak di kawasan pesisir Pantai Utara Pulau Jawa, memunyai kurang lebih 11 desa yang tersebar di 7 (tujuh) kecamatan yang sebagian besar masyarakatnya berprofesi sebagai nelayan, baik nelayan tangkap maupun nelayan tambak. Kabupaten Karawang dipilih sebagai lokasi penelitian karena kabupaten tersebut memunyai potensi perikanan tangkap yang cukup besar, dengan panjang pantai mencapai $84,23 \mathrm{Km}$. Selain itu, panjangnya garis pantai dan banyaknya jumlah sungai dan muara telah menjadikan Kabupaten Karawang sebagai daerah tempat berlabuhnya kapal-kapal penangkap ikan dan nelayan dari luar daerah (Dinas Kelauatan dan Perikanan Kabupaten Karawang, 2014). Potensi tersebut jika dikelola dengan optimal akan membantu meningkatkan kesejahteraan nelayan.

Namun seperti halnya kondisi masyarakat nelayan pada umumnya, nelayan di Kabupaten Karawang sebagian besar masuk dalam kategori masyarakat miskin secara ekonomi maupun sosial mereka masih tertinggal dibandingkan dengan kelompok masyarakat lainnya. Hal ini sejalan dengan apa yang dikatakan Kusnadi bahwa kondisi masyarakat pesisir atau masyarakat nelayan di berbagai kawasan pada umumnya ditandai dengan adanya beberapa ciri, seperti kemiskinan, keterbelakangan sosial budaya, dan rendahnya SDM karena sebagian besar penduduknya hanya lulus sekolah dasar atau belum tamat sekolah dasar, serta lemahnya fungsi dari keberadaan kelompok usaha (Belda, 2012).

Kondisi nelayan yang menyebabkan berbagai keterbelakangan tersebut terjadi karena akses mereka terhadap informasi publik masih sangat terbatas. Keterbatasan tersebut berkaitan erat dengan kondisi nelayan yang miskin sehingga mereka tidak bisa mengakses informasi publik dari berbagai media yang saat ini berkembang cukup pesat.

Penelitian mengenai opini nelayan terhadap akses informasi publik, belum banyak dilakukan sehingga kebijakan mengenai akses informasi bagi nelayan dan informasi serta data yang akurat yang dibutuhkan nelayan belum diketahui secara pasti oleh para pemangku kebijakan.

Berdasarkan uraian di atas maka permasalahan yang akan diangkat dalam penelitian ini adalah sejauhmana opini nelayan tentang akses informasi publik? Tujuan penelitian ini adalah: 1) Ingin menganalisis keyakinan nelayan tentang akses informasi publik; 2) Ingin menganalisis penilaian nelayan tentang akses informasi publik; 3) Ingin menganalisis kecenderungan nelayan tentang akses informasi publik. Sementara manfaat dari penelitian ini adalah 
memberikan data/rekomendasi kepada Kementerian Kominfo RI khususnya Dirjen Aptika dan Dirjen IKP mengenai opini nelayan tentang akses informasi publik.

\section{LANDASAN KONSEP}

\section{Penelitian Terdahulu}

Penelitian sejenis yang pernah dilakukan di antaranya adalah kajian karakteristik nelayan terhadap akses sumber informasi (Kasus di Desa Parangtritis Kecamatan Kretek Kabupaten Bantul Yogyakarta) yang ditulis oleh E. Sugiharto, dkk dan Pola Penggunaan Televisi di Kalangan Nelayan yang ditulis oleh Ria Rahajeng. Secara ringkas kedua penelitian tersebut dirangkum pada tabel 1(satu).

Perbedaan penelitian opini nelayan tentang akses informasi publik dengan penelitian sebelumnya pertama dari sisi lokasi dan juga objek, fokus, tujuan, dan pendekatan penelitiannya. Dalam penelitian ini akan diteliti sejauhmana opini nelayan tentang akses informasi publik. Teknik analisis datanya menggunakan tabel frekuensi dan garis kontinum untuk mengetahui seberapabesar opini dari nelayan tentang akses informasi publik, akan diketahui apakah opini nelayan tentang akses informasi publik positif atau negatif atau netral.

\section{Opini Nelayan tentang Akses Informasi Publik}

Nelayan menurut Undang-Undang No 31 Tahun 2004 tentang Perikanan, adalah orang yang mata pencahariannya melakukan penangkapan ikan. Nelayan juga bisa didefinisikan sebagai suatu kelompok masyarakat yang kehidupannya tergantung langsung pada hasil laut, baik dengan cara melakukan penangkapan ataupun budidaya. Mereka pada umumnya tinggal di pantai, sebuah lingkungan permukiman yang dekat dengan lokasi kegiatannya (Sipahelut, 2010). Namun demikian tidak banyak masyarakat yang melirik profesi nelayan. Kurangnya minat masyarakat khususnya generasi muda untuk menekuni profesi nelayan karena stigma nelayan yang saat ini identik dengan kemiskinan. Kemiskinan salah satunya terjadi karena minimnya akses mereka terhadap berbagai sumber informasi publik.

Lahirnya Undang-Undang No. 14 Tahun 2008 tentang Keterbukaan Informasi Publik (KIP), telah membawa kegembiraan bagi sejumlah pihak, karena UU tersebut menjanjikan kemudahan bagi masyarakat termasuk di dalamnya nelayan, untuk mendapatkan dan mengakses informasi publik melalui berbagai sumber-sumber informasi dengan mudah, murah, cepat, dan akurat. Keberadaan UU KIP tentunya akan mengundang opini dari masyarakat tidak terkecuali masyarakat nelayan, apakah memang publik akan mudah, cepat, murah, dan akurat dalam mendapatkan dan mengakses informasi yang dibutuhkan. Opini merupakan pernyataan dari sikap, dan opini dapat berubah-ubah dalam hal intensitas dan stabilitasnya. Noelle Neumann dalam Morissan (2013) menyatakan bahwa opini adalah derajat persetujuan atau derajat kesepakatan dari suatu masyarakat tertentu.

Selanjutnya dikatakan, opini publik adalah sikap atau perilaku yang harus dikemukakan seseorang di depan publik jika ia tidak ingin dirinya terisolasi dalam wilayah kontroversi atau perubahan.

Neolle Neumann (1993) dalam West dan Turner (2013) memisahkan opini publik menjadi dua istilah yang terpisah yakni opini dan publik. James Bryce (1924) dalam Nimmo (2005) menyebutkan bahwa opini publik adalah kumpulan pendapat orang mengenai hal ihwal yang memengaruhi atau menarik minat komunitas. Nimmo mengatakan bahwa semua opini mencerminkan suatu organisasi yang kompleks yang terdiri dari 3 komponen: 1) Keyakinan: seseorang yang memiliki keyakinan tentang suatu hal akan memiliki persepsi tentang suatu hal tersebut. 


\section{Tabel 1}

Perbedaan Penelitian Opini Nelayan tentang Akses Informasi Publik dengan Penelitian Terdahulu

\begin{tabular}{|c|c|c|c|}
\hline & \multicolumn{3}{|c|}{ Judul Penelitian } \\
\hline & $\begin{array}{c}\text { Kajian Karakteristik Nelayan } \\
\text { Terhadap Akses Sumber } \\
\text { Informasi (Kasus Di Desa } \\
\text { Parangtritis Kecamatan Kretek } \\
\text { Kabupaten Bantul } \\
\text { Yogyakarta) }\end{array}$ & $\begin{array}{c}\text { Pola Penggunaan Televisi di } \\
\text { Kalangan Nelayan (Studi Kasus } \\
\text { di Kelurahan Kutawaru, } \\
\text { Kecamatan Cilacap Tengah, } \\
\text { Kabupaten Cilacap, Jawa } \\
\text { Tengah) }\end{array}$ & $\begin{array}{l}\text { Opini Nelayan tentang Akses } \\
\text { Informasi Publik }\end{array}$ \\
\hline Penulis & $\begin{array}{l}\text { E.Sugiharto, A.V.S Hubais, } \\
\text { Gadjito, F.Rohadji }\end{array}$ & Ria Rahajeng & C.Suprapti Dwi Takariani \\
\hline $\begin{array}{l}\text { Deskripsi } \\
\text { Penelitian }\end{array}$ & 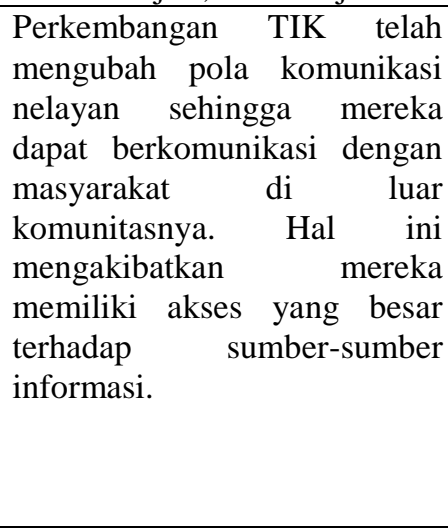 & $\begin{array}{l}\text { Terdapat kesenjangan informasi } \\
\text { yang disebabkan masih } \\
\text { terbatasnya infrastruktur di } \\
\text { daerah pedesaan dan daerah } \\
\text { terpencil sehingga masih } \\
\text { kesulitan untuk mengakses } \\
\text { informasi yang mereka } \\
\text { butuhkan. Masyarakat nelayan } \\
\text { di daerah tersebut hidup dalam } \\
\text { keterbatasan akses informasi. } \\
\text { Subjek dari penelitian ini adalah } \\
\text { nelayan Kelurahan Kutawaru } \\
\text { Cilacap. }\end{array}$ & $\begin{array}{l}\text { Secara geografis } \\
\text { terletak di posisi yang cukup } \\
\text { strategis dan memiliki kekayaan } \\
\text { laut yang cukup potensial. Jika } \\
\text { kekayaan tersebut dimanfaatkan } \\
\text { secara optimal maka bisa menjadi } \\
\text { tumpuan pembangunan ekonomi } \\
\text { nasional. karena sampai saat ini } \\
\text { SDM nelayan masih rendah. } \\
\text { SDM yang rendah bisa terjadi } \\
\text { karena akses informasi yang } \\
\text { rendah. }\end{array}$ \\
\hline $\begin{array}{c}\text { Fokus } \\
\text { Penelitian }\end{array}$ & $\begin{array}{l}\text { Karakteristik nelayan dan } \\
\text { akses sumber informasi } \\
\text { nelayan serta hubungan } \\
\text { karakteristik dan akses sumber } \\
\text { informasi nelayan. }\end{array}$ & $\begin{array}{l}\text { Motif-motif yang mendasari } \\
\text { dalam menonton televisi dan } \\
\text { pengaruh televisi terhadap } \\
\text { profesi sebagai nelayan. }\end{array}$ & $\begin{array}{l}\text { Sejauhmana opini nelayan tentang } \\
\text { akses informasi publik? }\end{array}$ \\
\hline $\begin{array}{l}\text { Tujuan } \\
\text { Penelitian }\end{array}$ & $\begin{array}{l}\text { Menjawab permasalahan } \\
\text { seputar karakteristik dan akses } \\
\text { sumber informasi nelayan. }\end{array}$ & $\begin{array}{l}\text { Tujuan penelitian untuk } \\
\text { mendeskripsikan pola } \\
\text { penggunaan televisi di kalangan } \\
\text { nelayan di Kelurahan Kutawaru, } \\
\text { Kecamatan Cilacap Tengah, } \\
\text { Kabupaten Cilacap, Jawa } \\
\text { Tengah. }\end{array}$ & $\begin{array}{l}\text { Ingin mengetahui dan } \\
\text { menganalisis opini nelayan } \\
\text { tentang akses informasi publik. }\end{array}$ \\
\hline $\begin{array}{c}\text { Pendekata } \\
\text { n } \\
\text { Penelitian }\end{array}$ & Deskriptif korelasional. & $\begin{array}{lll}\text { Deskriptif kualitatif, } & \text { yang } \\
\text { menggunakan metode } & \text { studi } \\
\text { kasus. } & & \\
\end{array}$ & Deskriptif kuantitatif \\
\hline $\begin{array}{l}\text { Teknik } \\
\text { Pengumpul } \\
\text { an data }\end{array}$ & $\begin{array}{l}\text { Kuesioner (angket) kepada } \\
\text { para nelayan, secara acak } \\
\text { sederhana dan uji statistik } \\
\text { dengan menggunakan uji } \\
\text { statistik korelasi Rank } \\
\text { Spearman. }\end{array}$ & $\begin{array}{lr}\text { Pengumpulan } & \text { data } \\
\text { menggunakan } & \text { teknik } \\
\text { wawancara } & \text { mendalam, } \\
\text { observasi dan } & \text { dokumen. } \\
\text { Informan dipilih } & \text { dengan } \\
\text { menggunakan metode snowball } & \\
\text { sampling. } & \end{array}$ & $\begin{array}{l}\text { Angket kepada nelayan secara } \\
\text { acak sederhana dan analisis } \\
\text { menggunakan tabel frekuensi dan } \\
\text { garis kontinum. }\end{array}$ \\
\hline
\end{tabular}

Sumber: Diolah dari berbagai sumber.

Keyakinan berkaitan erat dengan aspek kognitif. Menyangkut percaya atau tidak terhadap suatu hal; 2) Nilai: preferensi yang dimiliki seseorang untuk tujuan tertentu. Nilai berkaitan erat dengan aspek afektif. Menyangkut perasaan suka atau tidak suka terhadap suatu hal; 3) Ekspektasi: seseorang mengonstruksikan tindakan dengan membawa pengalaman masa lalu untuk digunakan pada saat ini dalam rangka mengakses kemungkinan pada masa yang akan datang. Ekspektasi berkaitan erat dengan aspek konatif (kecenderungan).

Informasi akan memberi manfaat bagi penggunanya jika informasi tersebut bisa diakses. Akses informasi sendiri bisa 
dikatakan sebagai kemudahan yang diberikan kepada seseorang atau masyarakat untuk memeroleh informasi. Akses informasi juga bisa diartikan sebagai ketersediaan informasi bagi seseorang untuk bisa dibaca atau digunakan sesuai dengan kebutuhannya (Astuti, 2012). Ketersediaan informasi bisa diperoleh nelayan melalui berbagai sumber seperti media massa (televisi, radio, surat kabar, internet) maupun dari media interpersonal (Petugas Penyuluh dari instansi pemerintah) yang dalam penelitian ini dikhususkan pada petugas perikanan kabupaten, petugas perikanan kecamatan, dan kelompok/rukun nelayan, karena petugaspetugas tersebutlah yang paling banyak behubungan dengan nelayan.

Oleh karena itu setiap informasi harus berkualitas agar bisa memberikan manfaat bagi penggunanya. Kualitas informasi tergantung dari tiga hal yakni (Prabadipta, 2013): 1) Akurat, berarti informasi harus bebas dari kesalahan-kesalahan dan harus jelas mencerminkan maksudnya; 2) Tepat pada waktunya, berarti informasi yang diterima tidak boleh terlambat; 3) Relevan, berarti informasi tersebut memunyai manfaat bagi pemakainya.

\section{METODE PENELITIAN}

Paradigma penelitian ini adalah positivism, dengan pendekatan kuantitatif, dan metode survei. Sifat penelitian adalah deskriptif. Metode survei yaitu suatu upaya mengumpulkan informasi dari responden dengan menggunakan kuesioner dan pengambilan sampel dari populasi yang diamati (Singarimbun, 1989).

Populasi dalam penelitian ini adalah masyarakat yang berprofesi sebagai nelayan tangkap baik nelayan penuh, nelayan sambilan utama, maupun nelayan sambilan tambahan, di Kabupaten Karawang Provinsi Jawa Barat. Menurut data dari Dinas Perikanan dan Kelautan Provinsi Jawa Barat jumlah nelayan di Kabupaten Karawang adalah 6.691 orang nelayan. Untuk penentuan lokasi/wilayah di tingkat kecamatan dilakukan dengan cara acak sederhana.

Teknik sampling yang digunakan untuk pengambilan responden untuk tiap kecamatan dilakukan secara proportional sampling yaitu metode pengambilan sampel secara proporsional berdasarkan subpopulasi. Penentuan responden di tingkat kecamatan dilakukan secara acak sederhana. Jumlah sampel secara menyeluruh ditetapkan berdasarkan rumus Tarro Yamane sebagai berikut: Rakhmat (2012)

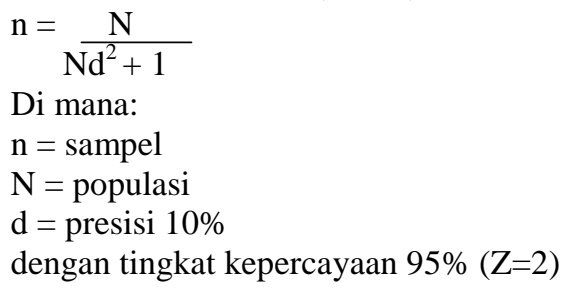

$$
\begin{aligned}
\mathrm{n} & =\frac{6.691}{6.691(0,10)^{2}}+1 \\
& =98,52(99) \text { sebagai sampel responden }
\end{aligned}
$$

Jumlah sampel responden per kecamatan terpilih ditetapkan berdasarkan proporsi populasi dari masing-masing kecamatan, yakni: Kecamatan Pedes 5 (lima) responden, Kecamatan Tempuran 35 responden, Kecamatan Cilamaya Wetan 24 responden, Kecamatan Cilamaya Kulon 28 responden, dan Kecamatan Cibuaya 7 (tujuh) responden.

Pengumpulan data dilakukan dengan mengelompokkan data menjadi dua yaitu data primer dan sekunder. Data primer diperoleh peneliti dari responden, dengan menggunakan kuesioner yaitu dengan memberikan seperangkat daftar pertanyaan pada responden (nelayan). Penyusunan kuesioner dengan menggunakan skala Likert. Jawaban setiap item instrumen yang menggunakan skala Likert memunyai gradasi dari sangat positif sampai sangat negatif yang dapat berupa katakata untuk keperluan analisis kuantitatif. Skor masing-masing jawaban adalah sangat setuju $=5, \quad$ setuju $=4, \quad$ ragu-ragu $=3$, tidak setuju $=2$, sangat tidak setuju=1. Sementara data sekunder adalah data berupa dokumen, catatan, laporan, dan lain sebagainya, oleh karenanya untuk mendapatkan informasi dari data sekunder, peneliti menggunakan teknik pengumpulan data dengan menelusuri 
catatan-catatan, laporan, dokumen, dan sebagainya.

\section{Operasionalisasi Konsep}

1. Nelayan: yang dimaksud nelayan dalam penelitian ini adalah orang yang mata pencahariannya menangkap ikan dengan menggunakan alat-alat yang sederhana hingga menggunakan alat yang modern yang terdiri dari nelayan tangkap baik nelayan tangkap di laut maupun nelayan tambak di Kabupaten Karawang Provinsi Jawa Barat.

2. Informasi Publik adalah informasi yang diberikan oleh media interpersonal (petugas penyuluh perikanan kabupaten, petugas penyuluh perikanan kecamatan, dan kelompok/rukun nelayan) dan media massa (elektronik dan cetak), dan internet.

3. Opini Nelayan adalah kumpulan pendapat nelayan mengenai informasi publik yang memengaruhi atau menarik minat nelayan, adapun indikatornya adalah keyakinan nelayan, penilaian nelayan, dan kecenderungan perilaku nelayan.

4. Akses Informasi Publik adalah kemudahan nelayan dalam mendapatkan informasi. Indikatornya adalah kemudahan dan keakuratan.

Teknik analisis data yang digunakan adalah analisis univariat, pada umumnya analisis ini hanya menghasilkan distribusi dan persentase dari setiap variabel (Notoatmodjo, 2005). Analisis dilakukan dengan menggunakan statistik deskriptif dan penyajian data dalam bentuk tabel frekuensi dan garis kontinum. Nilai garis kontinum diperoleh dari perkalian frekuensi dengan value atau nilai yang telah ditentukan. Total penjumlahan akan diwakilkan oleh garis putus-putus. Jika jumlah dari hasil perkalian tersebut cenderung ke kanan dari batas garis ragu-ragu (R) pada garis kontinum, maka penilaian responden terhadap indikator semakin positif, sebaliknya bila jumlah dari hasil perkalian cenderung ke arah kiri dari batas ragu-ragu (R) pada garis kontinum, maka penilaian responden terhadap indikator semakin negatif. Jika tepat pada garis ragu- ragu, maka responden bersifat netral atau tidak memihak.

\section{HASIL PENELITIAN DAN PEMBAHASAN}

\section{Identitas Responden}

Jumlah sampel dalam penelitian ini adalah 99 orang yang tersebar di 5 (lima) kecamatan nelayan di Kabupaten Karawang Provinsi Jawa Barat. Seluruh angket yang disebarkan kepada para nelayan tersebut ada 18 angket yang tidak layak untuk dianalisis, karena kekuranglengkapan jawaban sehingga hanya 80 angket memenuhi syarat untuk dianalisis.

Usia responden berkisar antara 15 hingga lebih dari 51 tahun, yang terbanyak adalah responden yang berusia antara 46 hingga 50 tahun. Rentang usia 46 - 50 tahun dapat dikatakan sebagai kategori usia tua (lihat tabel 2 (dua)).

Pendidikan merupakan salah satu indikator keberhasilan pembangunan terutama untuk mengukur kualitas sumber daya manusianya. Dalam Peraturan Daerah Kabupaten karawang Nomor 2 Tahun 2010 tentang Rencana Pembangunan Jangka Panjang Daerah Kabupaten Karawang Tahun 2005-2025, disebutkan bahwa kualitas sumber daya manusia di Kabupaten Karawang masih tergolong rendah. Data ini menguatkan hasil penelitian yang peneliti lakukan, bahwa ternyata tingkat pendidikan responden masih tergolong rendah, di mana 39 responden $(48,8 \%)$ tamat sekolah dasar, 22 responden $(27,5 \%)$ tidak tamat sekolah dasar, 11 responden $(13,8 \%)$ tidak tamat SMP, 3 (tiga) responden $(3,7 \%)$ tamat SMP, 2 (dua) responden $(2,5 \%)$ tidak tamat SMA, dan 3 (tiga) responden $(3,7 \%)$ tamat SMA.

Dilihat dari sisi penghasilan rata-rata responden berpenghasilan di bawah besaran Upah Minimum Kota/Kabupaten (UMK) Kabupaten Karawang (lihat tabel 3 (tiga)) yang berdasarkan SK Gubernur Jawa Barat tahun 2015 No.560/Kep.1581 Bangsos/2014 tentang UMK tahun 2015, di mana UMK 
Kabupaten Karawang sebesar Rp2.957.450. Profesi responden yang rata-rata merupakan nelayan tradisional yakni yang hanya mengguna kapal penangkap ikan di bawah 5 (lima) gross tonnage (GT) menjadikan mereka sulit untuk mencari lokasi di mana ikan-ikan berada karena mereka hanya mampu melaut dalam jarak dekat saja.

Rendahnya pendapatan responden juga dipengaruhi oleh cuaca atau iklim, belum lagi jeratan dari para tengkulak, sehingga responden tidak memiliki posisi tawar yang sesuai dengan harga pasar ketika mereka menjual hasil tangkapanya. Sarana dan prasarana yang kurang memadai terjadi karena responden tidak memunyai modal yang cukup sehingga mereka terus menerus mengandalkan modal dari para tengkulak.

Hasil penelitian mengenai identitas responden memerlihatkan bahwa responden masuk dalam kategori miskin. Terlihat dari usia yang rata-rata tidak muda, tingkat pendidikan yang rendah, dan penghasilan yang rendah. Ketiga hal tersebut menjadi problem bagi responden, karena mereka akan sulit untuk mengakses informasi publik yang saat ini membanjiri berbagai media konvensional maupun media baru. Sehingga mereka hanya mengandalkan informasi dari media interpersonal seperti penyuluh perikanan dan ketua kelompok/rukun nelayan. Hasil penelitian tersebut juga memerlihatkan bahwa regenerasi nelayan tampak jalan di tempat karena generasi muda di daerah nelayan tidak tertarik lagi menekuni profesi sebagai nelayan dan memilih menekuni profesi lain.

\section{Terpaan Media}

Hasil penelitian menunjukkan, dari 80 responden, hanya $1,25 \%$ yang tidak memiliki televisi, $48,75 \%$ menonton televisi setiap hari dan $38,75 \%$ menyatakan intensitas menonton lebih dari tiga jam. Hal ini membuktikan jika televisi masih menjadi media yang paling favorit di mata responden. Namun demikian televisi tampaknya hanya menjadi media yang sekedar memberi hiburan saja, lihat tabel 4 (empat).

Berdasarkan hasil penelitian tidak ditemukan responden yang memiliki radio maupun surat kabar. Responden sudah lama meninggalkan radio sebagai media untuk mencari hiburan maupun informasi, sementara surat kabar sulit ditemukan di lokasi penelitian. Handphone (HP) merupakan alat komunikasi yang muncul di era globalisasi ternyata menjadi media komunikasi dan informasi yang banyak dimiliki oleh responden. Hasil penelitian menunjukkan bahwa 78 responden $(97,5 \%)$ memiliki HP dan hanya 2 (dua) responden $(2,5 \%)$ yang tidak memiliki HP, ini berarti bahwa HP telah menjadi media yang cukup favorit bagi responden untuk berkomunikasi.

Tabel 2

Usia Responden

\begin{tabular}{llcc}
\hline No. & Uraian & Frekuensi & Persentase \\
\hline 1. & $15-20$ tahun & 2 & $2,5 \%$ \\
2. & $21-25$ tahun & 7 & $8,8 \%$ \\
3. & $26-30$ tahun & 9 & $11,3 \%$ \\
4. & $31-35$ tahun & 10 & $12,5 \%$ \\
5. & $36-40$ tahun & 12 & $15,0 \%$ \\
6. & $41-45$ tahun & 16 & $20,0 \%$ \\
7. & $46-50$ tahun & 17 & $21,3 \%$ \\
8. & Lebih dari 51 tahun & 7 & $8,8 \%$ \\
\hline
\end{tabular}

Sumber: Hasil Penelitian Tahun 2015. 
Tabel 3

Penghasilan Responden dalam satu bulan

\begin{tabular}{llcc}
\hline No & \multicolumn{1}{c}{ Uraian } & Frekuensi & Persentase \\
\hline 1. & Kurang dari Rp. 500.000 & 23 & $28,7 \%$ \\
2. & Rp. 500.000 - Rp. 750.000 & 18 & $22,5 \%$ \\
3. & Rp. 750.000 - Rp. 1.000.000 & 20 & $25,0 \%$ \\
4. & Rp. 1.000.000 - Rp. 1.250.000 & 11 & $13,7 \%$ \\
5. & Rp. 1.250.000 - Rp. 1.500.000 & 5 & $6,3 \%$ \\
6. & Di atas Rp. 1.500.000 & 3 & $3,7 \%$ \\
\hline & Total & 80 & $100,0 \%$ \\
\hline
\end{tabular}

Sumber: Hasil Penelitian Tahun 2015.

Kehadiran internet belum begitu dirasakan manfaatnya bagi sebagian besar responden karena berbagai hambatan, seperti belum bagusnya jaringan internet di lokasi penelitian dan faktor sumber daya manusia yang masih awam terhadap internet. Hasil penelitian menunjukkan 12 responden $(15 \%)$ yang bisa menggunakan internet sisanya 68 responden $(85 \%)$ belum bisa menggunakan internet.

Sumber-sumber informasi dari media interpersonal yang memberikan akses informasi kepada responden dalam penelitian ini adalah petugas penyuluh perikanan dari Dinas Kelautan dan Perikanan baik tingkat kabupaten maupun tingkat kecamatan dan sumber informasi dari ketua kelompok/rukun nelayan. Dari ketiga petugas tersebut ternyata ketua kelompok/rukun nelayanlah yang paling mudah ditemui dan memberikan informasi kepada responden, hal ini dikemukakan oleh 67 responden $(83,8 \%)$. Sementara 10 responden $(12,5 \%)$ berpendapat bahwa petugas penyuluh instansi pemerintah tingkat kecamatanlah yang paling mudah ditemui dan memberikan informasi kepada responden, dan 3 (tiga) responden $(3,8 \%)$ berpendapat petugas penyuluh dari instansi pemerintah yang paling mudah ditemui dan memberikan informasi kepada responden. Saat ini responden masih mengandalkan media interpersonal (seperti petugas penyuluh perikanan dari kabupaten dan kecamatan serta ketua kelompok/rukun nelayan) untuk mendapatkan informasi publik yang mereka butuhkan.

Informasi publik yang biasanya diakses/dicari responden dari petugas penyuluh instansi pemerintah baik tingkat kabupaten/kecamatan maupun dari ketua kelompok/rukun nelayan, lihat tabel 5 (lima). Informasi publik mengenai pemberdayaan nelayan menjadi informasi publik yang paling banyak dibutuhkan oleh responden. Hal ini sangat wajar karena banyak program-program pemberdayaan yang digulirkan oleh pemerintah belum mampu untuk meningkatkan kesejahteraan bagi nelayan, atau terkadang informasi publik mengenai program-program pemberdayaan nelayan tidak diketahui oleh responden karena keterbatasan akses informasi.

Sementara intensitas petugas penyuluh pemerintah tingkat kabupaten dalam memberikan informasi publik, hanya 6 (enam) $(7,5 \%)$ responden yang mengaku petugas penyuluh perikanan kabupaten cukup sering memberikan informasi tersebut dan 74 $(92,5 \%)$ mengaku petugas penyuluh perikanan kabupaten jarang memberikan informasi tersebut.

Selain petugas penyuluh pemerintah tingkat kabupaten, di lokasi penelitian juga ditemukan petugas penyuluh pemerintah tingkat kecamatan. Hasil penelitian menunjukkan bahwa petugas penyuluh dari kecamatan sering dalam memberikan informasi publik demikian pengakuan dari 72 $(90,0 \%)$ responden dan hanya 8 (delapan) $(10,0 \%)$ responden yang mengaku bahwa petugas penyuluh kecamatan jarang memberikan informasi publik kepada responden.

Di lokasi penelitian ditemukan juga kelompok atau rukun nelayan, di mana kelompok tersebut memunyai ketua yang juga memberikan informasi publik untuk keperluan anggotanya. Hasil penelitian 
menunjukkan bahwa ketua kelompok/rukun nelayanlah yang dinilai responden paling intensif memberikan informasi publik yang dibutuhkan oleh nelayan, terlihat dari jawaban responden bahwa 9 (sembilan) $(11,3 \%)$ menyatakan sangat sering, 19 $(23,7 \%)$ menyatakan sering, $33 \quad(41,3 \%)$ menyatakan cukup sering dan hanya 19 $(23,75 \%)$ responden yang menyatakan jarang.

Dari ketiga media interpersonal, ternyata ketua kelompok/rukun nelayan yang paling mudah ditemui responden dan paling sering memberikan informasi publik yang dibutuhkan oleh responden. Media interpersonal masih menjadi andalan bagi responden untuk mencari dan mendapatkan informasi publik yang mereka butuhkan meskipun responden belum sepenuhnya mendapatkan informasi sesuai dengan harapannya. Media konvensional seperti televisi dan juga alat komunikasi seperti HP belum digunakan oleh responden sebagai media untuk mendapatkan informasi publik.
Televisi hanya sebatas digunakan untuk mencari hiburan karena televisi sendiri tampaknya belum banyak memberikan informasi yang bisa dimanfaatkan oleh responden. Sementara HP hanya digunakan responden sebatas untuk berkomunikasi dan bermain game.

\section{Opini tentang Akses Informasi Publik (Keyakinan Responden tentang Akses Informasi Publik)}

Responden ternyata masih mengandalkan media interpersonal untuk mengakses informasi publik dibandingkan media massa maupun internet. Karena di lokasi penelitian responden hanya memiliki televisi dan HP sebagai sarana bagi responden untuk mendapatkan hiburan dan berkomunikasi. Oleh karenanya dalam uraian ini hanya akan dianalisis opini responden tentang akses informasi publik dari media interpersonal yang meliputi keyakinan,

\section{Tabel 4}

\section{Jenis Acara Di Televisi yang Paling Sering Ditonton}

\begin{tabular}{llcc}
\hline No & \multicolumn{1}{c}{ Jenis Acara yang Paling Sering Ditonton } & Frekuensi & Persentase \\
\hline 1. & Berita & 21 & $26,25 \%$ \\
2. & Film/sinetron & 50 & $62,5 \%$ \\
3. & Musik & 2 & $2,1 \%$ \\
4. & Olah raga & 1 & $1,0 \%$ \\
5. & Reality show & 2 & $2,1 \%$ \\
7. & Talk show & 1 & $1,0 \%$ \\
8. & Kuis & 2 & $2,1 \%$ \\
9. & Pendidikan & - & - \\
\hline & Total & 79 & $100,0 \%$ \\
\hline
\end{tabular}

Sumber: Hasil Penelitian Tahun 2015.

Tabel 5

Informasi Publik yang Biasanya Diakses/Dicari Responden dari Media Interpersonal

\begin{tabular}{llc}
\hline No & \multicolumn{1}{c}{ Uraian } & Frekuensi \\
\hline 1. & Informasi pemodalan & 53 \\
2. & Informasi tentang pemasaran hasil tangkapan ikan & 25 \\
3. & Informasi program pemberdayaan untuk nelayan & 79 \\
4. & Informasi teknologi perikanan. & 11 \\
5. & Informasi pengolahan hasil tangkapan ikan & 2 \\
6. & Informasi pengadaan sarana dan prasarana bagi nelayan & 4 \\
7. & Informasi mengenai cuaca & 14 \\
\hline & Total & 188 \\
\hline
\end{tabular}

Sumber: Hasil Penelitian Tahun 2015 (Jawaban lebih dari satu). 
penilaian, dan kecenderungan perilaku responden berkaitan dengan akses informasi publik.

Keyakinan responden tentang kemudahan dalam mengakses informasi publik dari petugas penyuluh perikanan kabupaten berdasarkan hasil penelitian adalah 3 (tiga) $(3,8 \%)$ responden menyatakan sangat setuju, $26(32,5 \%)$ menyatakan setuju, 18 $(22,5 \%)$ responden menyatakan ragu-ragu, 19 $(23,8 \%)$ responden menyatakan tidak setuju, dan 14 (17,5\%) responden menyatakan sangat tidak setuju. Hasil perkalian memerlihatkan total skor adalah 225, angka ini kurang dari batas netral yakni 240, dapat dikatakan opini responden pada dimensi ini adalah negatif (lihat gambar 1 (satu)).

Hasil penelitian mengenai keyakinan responden terhadap kemudahan mengakses informasi publik dari petugas penyuluh perikanan kecamatan adalah 7 (tujuh) $(8,75 \%)$ responden menyatakan sangat setuju, $35(43,75 \%)$ responden menyatakan setuju, $21(26,75 \%)$ responden menyatakan raguragu, $26(20 \%)$ responden menyatakan tidak setuju, dan 1 (satu) (1,25\%) responden menyatakan sangat tidak setuju. Hasil perkalian memerlihatkan total skor adalah 271 jika digambarkan dalam garis kontinum melebihi angka 240. Dapat dikatakan opini responden pada dimensi ini adalah positif.

Hasil tentang keyakinan responden terhadap kemudahan mendapatkan informasi publik dari ketua kelompok/rukun nelayan, di mana $21(27,55 \%)$ responden menyatakan sangat setuju, $47(54,08 \%)$ responden menyatakan setuju, 9 (Sembilan) $(12,24 \%)$ responden menyatakan ragu-ragu, 3 (tiga) $(6,12 \%)$ responden menyatakan tidak setuju.
Peneliti mendapatkan hasil perkalian dari frekuensi dan value untuk digambarkan pada garis kontinum yakni sebesar 326. Angka ini terletak ke kanan dari garis netral yakni 240 . Ini berarti opini atau pendapat responden untuk dimensi ini bernilai positif. Keyakinan responden tentang kemudahan dalam mengakses infromasi publik dari ketiga media interpersonal menunjukkan responden yakin bahwa informasi publik dari petugas penyuluh perikanan kecamatan mudah diakses, namun responden lebih yakin lagi jika informasi publik dari ketua kelompok/rukun nelayan lebih mudah diakses dibanding dengan informasi dari petugas penyuluh perikanan kabupaten.

Setiap informasi publik yang diakses responden diyakini menambah pengetahuan. Meskipun akses informasi tersebut baru sebatas dari media interpersonal. Hal tersebut terungkap dari hasil penelitian dari 80 responden, 76 responden $(95 \%)$ responden mengakui bahwa informasi publik tersebut sangat menambah pengetahuan responden. Namun responden ragu-ragu jika informasi publik yang mereka akses dari media interpersonal dapat menambah penghasilan, seperti diungkapkan oleh 67 responden $(83,8 \%)$. Keragu-raguan tersebut sangat beralasan karena responden hanya sebatas mendapatkan informasi, sementara mereka tidak mengetahui bagaimana tindaklanjut dari informasi yang diakses tersebut agar bisa menambah penghasilan.

Keyakinan responden tentang akurasi informasi publik dari petugas penyuluh perikanan kabupaten, hasil penelitian menunjukkan bahwa 1 (satu) (1,25\%)

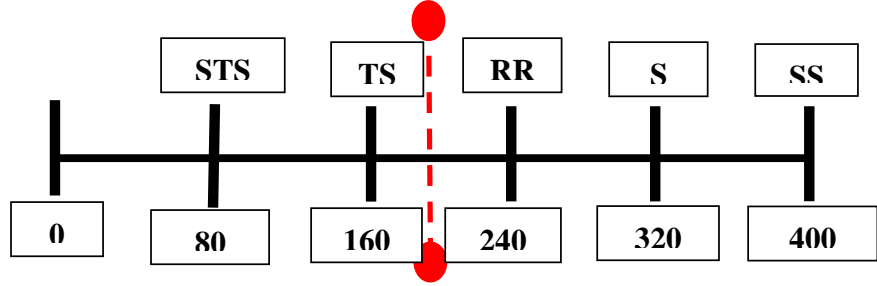

Gambar 1

Garis Kontinum Keyakinan Responden tentang Kemudahan Mengakses Informasi Publik Dari Petugas Penyuluh Perikanan Kabupaten 
responden sangat setuju, $21 \quad(26,3 \%)$ responden setuju, 38 (47,5\%) responden ragu-ragu, $18(22,5 \%)$ responden tidak setuju, dan $2(2,5 \%)$ responden sangat tidak setuju. Peneliti mendapatkan hasil perkalian dari frekuensi dan value yakni sebesar 297. Angka ini jika digambarkan pada garis kontinum terletak di sebelah kanan garis netral yakni 240, dapat dikatakan opini responden pada dimensi ini adalah positif.

Sementara itu keyakinan responden tentang akurasi informasi publik dari petugas penyuluh perikanan kecamatan, hasil penelitian menunjukkan bahwa $1(1,25 \%)$ responden menyatakan sangat setuju, 29 $(36,25 \%)$ responden setuju, $30 \quad(37,5 \%)$ responden ragu-ragu, $11(13,75 \%)$ responden tidak setuju, dan $9(11,25 \%)$ responden sangat tidak setuju. Peneliti mendapatkan hasil perkalian dari frekuensi dan value untuk digambarkan pada garis kontinum yakni sebesar 242. Angka ini terletak ke kanan dari garis netral yakni 240. Ini berarti opini atau pendapat responden untuk dimensi ini bernilai positif (lihat gambar 2 (dua)). Keyakinan responden tentang akurasi informasi publik dari ketua kelompok/rukun nelayan, hasil penelitian menunjukkan bahwa 5 (lima) responden $(6,3 \%)$ menyatakan sangat setuju, $43(53,8 \%)$ responden setuju, 21(26,3\%) responden ragu-ragu, $10(12,5 \%)$ responden menyatakan tidak setuju, dan 1 (1,25\%) responden menyatakan sangat tidak setuju. Hasil perkalian dari frekuensi dan value untuk digambarkan pada garis kontinum yakni sebesar 281. Angka ini terletak ke kanan dari garis netral yakni 240. Ini berarti opini atau pendapat responden untuk dimensi ini bernilai positif. Hasil penelitian mengenai keyakinan responden terhadap akurasi informasi publik dari ketiga media interpersonal adalah positif namun nilai dari keyakinan tertinggi adalah keakuratan informasi publik dari ketua kelompok/rukun nelayan.

\section{Penilaian Responden Tentang Informasi Publik dari Media Interpersonal}

Penilaian berkaitan erat dengan aspek afektif, menyangkut perasaan suka atau tidak suka, menarik tidak menarik terhadap suatu hal. Penilaian responden terhadap petugas penyuluh perikanan kabupaten, hasil penelitian menunjukkan bahwa 20 (25\%) responden menyatakan sangat setuju, 38 $(47,5 \%)$ responden menyatakan setuju, 13 $(16,3 \%)$ responden menyatakan ragu-ragu, dan $9(11,3 \%)$ responden menyatakan tidak setuju. Hasil perkalian dari frekuensi dan value untuk digambarkan pada garis kontinum yakni sebesar 309. Angka ini terletak ke kanan dari garis netral yakni 240. Ini berarti opini atau pendapat responden untuk dimensi ini bernilai positif.

Penilaian responden terhadap petugas penyuluh perikanan kecamatan, hasil penelitian menunjukkan bahwa $31(38,75 \%)$ responden menyatakan sangat setuju, 39 $(48,75 \%)$ responden menyatakan setuju, 11 $(13,75 \%)$ menyatakan ragu-ragu. Peneliti mendapatkan hasil perkalian dari frekuensi dan value sebesar 344. Angka ini jika digambarkan pada garis kontinum terletak ke kanan dari garis netral yakni 240. Ini berarti opini atau pendapat responden untuk dimensi ini bernilai positif.

Penilaian responden terhadap ketua kelompok/rukun nelayan, hasil penelitian menunjukkan bahwa $18(22,5 \%)$ responden menyatakan sangat setuju, $55 \quad(68,75 \%)$ responden menyatakan setuju, dan $7(8,75 \%)$ responden menyatakan ragu-ragu. Hasil perkalian dari frekuensi dan value untuk digambarkan pada garis kontinum yakni sebesar 331. Ini berarti opini atau pendapat responden untuk dimensi ini bernilai positif.

\section{Kecenderungan Perilaku Responden Dalam Mengakses Publik Informasi Publik}

Kecenderungan perilaku responden dalam mengakses informasi publik dari petugas penyuluh perikanan kabupaten, hasil penelitian menunjukkan, 1(satu) responden $(1,25 \%)$ menyatakan sangat setuju, 13 responden $(16,3 \%)$ menyatakan setuju, 24 responden $(30 \%)$ menyatakan ragu-ragu, 31 responden $(38,75 \%)$ menyatakan tidak setuju, dan 11 responden $(13,75 \%)$ menyatakan sangat tidak setuju. Hasil perkalian dari frekuensi dan value untuk digambarkan pada garis kontinum yakni sebesar 240. Angka ini 
terletak pada garis netral yakni 240. Ini berarti opini atau pendapat responden untuk dimensi ini bernilai netral.

Sementara itu kecenderungan perilaku responden dalam mengakses informasi publik dari petugas penyuluh perikanan kecamatan, diperoleh hasil sebagai berikut: 21 (26,3\%) responden menyatakan sangat setuju, 36 $(45 \%)$ responden menyatakan setuju, 15 $(18,75 \%)$ responden menyatakan ragu-ragu, dan $8(10 \%)$ responden menyatakan tidak setuju. Hasil perkalian dari frekuensi dan value untuk digambarkan pada garis kontinum yakni sebesar 310. Angka ini terletak ke kanan dari garis netral yakni 240. Ini berarti opini atau pendapat responden untuk dimensi ini bernilai positif.

Kecenderungan perilaku responden dalam mengakses informasi publik dari ketua kelompok/rukun nelayan, diperoleh hasil sebagai berikut: $31 \quad(38.75 \%)$ responden menyatakan sangat setuju, $47 \quad(58,75 \%)$ menyatakan setuju, dan $2(2,5 \%)$ responden menyatakan ragu-ragu. Hasil perkalian dari frekuensi dan value yakni sebesar 349. Angka ini jika digambarkan pada garis kontinum terletak ke kanan dari garis netral yakni 240. Ini berarti opini atau pendapat responden untuk dimensi ini bernilai positif.

Berdasarkan hasil penelitian, terlihat responden cenderung mengakses informasi ke petugas penyuluh perikanan kecamatan dan ketua kelompok/rukun nelayan. Kedekatan responden dengan tempat di mana petugas penyuluh perikanan kecamatan berada dan kesamaan profesi responden dengan ketua kelompok/rukun nelayan dan intensitas responden bertemu dengan petugas penyuluh perikanan kecamatan berada dan kesamaan profesi responden dengan ketua kelompok/rukun nelayan yang relatif lebih sering menjadi alasan mengapa responden cenderung mengakses informasi ke mereka di banding ke petugas penyuluh kabupaten. Kedekatan merupakan salah hal yang menentukan ketertarikan seseorang.

Berscheid dan Reis (1998) mengatakan bahwa orang yang paling sering dilihat, ditemui akan sangat mungkin disukai. Kesamaan profesi memberikan keleluasaan bagi responden untuk saling berbagi informasi. Seperti yang dikatakan Rakhmat (2012), kedekatan secara psikologis ternyata memberikan pengaruh yang luar biasa. Seseorang cenderung lebih menyenangi orang lain yang saling berdekatan, begitu pula dengan responden terhadap ketua kelompok/rukun nelayan, karena ketua kelompok/rukun nelayan juga berprofesi sebagai nelayan. Kedekatan seseorang akan memudahkan seseorang menyampaikan pesan-pesannya kepada orang lain. Selanjutnya dikatakan oleh Rakhmat (2012) bahwa hubungan interpersonal yang baik menyakup tiga unsur, meliputi sikap percaya, suportif, dan sikap terbuka. Hal tersebut juga diperkuat dengan hasil penelitian yang dilakaukan oleh Leon Festinger, Stanley Schachter, dan Kurt Back (1950) dalam Devito (1997) bahwa ketertarikan dipengaruhi oleh jarak yang dekat dan seringnya berinteraksi. Selain faktor kedekatan, faktor kredibilitas dari komunikator akan sangat memengaruhi kepercayaan terhadap pesan-pesan yang disampaikannya. Kredibilitas adalah

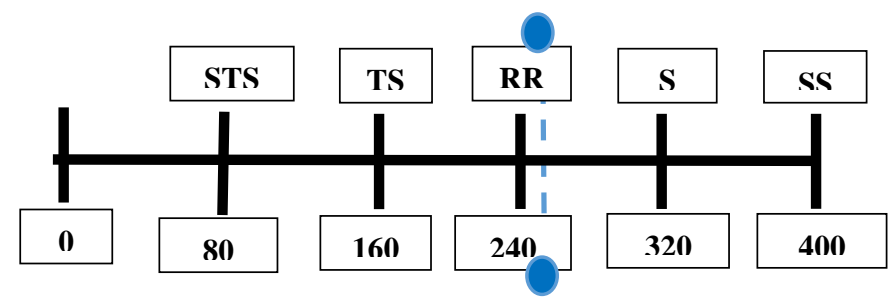

Gambar 2

Garis Kontinum Keyakinan Responden tentang Akurasi Informasi Publik Dari Petugas Penyuluh Perikanan Kecamatan 
seperangkat persepsi komunikan tentang sifat-sifat komunikator. Dalam definisi ini terkandung 2 hal yaitu (1) Kredibilitas adalah persepsi komunikan, jadi tidak inheren dalam diri komunikator; (2) kredibilitas berkenaan dengan sifat-sifat komunikator, yang selanjutnya akan disebut sebagai komponenkomponen kredibilitas (Rakhmat, 1994). Komponen kredibilitas yang paling penting adalah keahlian dan kepercayaan. Keahlian adalah penilaian komunikan mengenai kemampuan, keceradasan, pengalaman seorang komunikator. Komunikator yang dianggap memunyai keahlian yang tinggi biasanya akan lebih dihargai. Sementara kepercayaan adalah kesan komunikan tentang watak komunikator. Komunikan biasanya akan menilai apakah komunikator itu memunyai sifat jujur, tulus, sopan, dan etis (Rakhmat, 2012). Sikap dan perilaku dari ketiga media interpersonal yang jujur, tulus, dan sopan ternyata menjadi faktor tingginya keyakinan responden terhadap kemudahan dan keakuratan informasi publik yang disampaikan oleh media interpersonal tersebut.

\section{PENUTUP}

\section{Simpulan}

Opini responden tentang kemudahan mengakses informasi publik dari petugas penyuluh perikanan kabupaten adalah negatif. Sementara itu opini responden tentang kemudahan mengakses informasi publik dari petugas penyuluh perikanan kecamatan bernilai positif. Opini responden tentang kemudahan dalam mendapatkan informasi dari ketua kelompok/rukun nelayan bernilai positif. Responden yakin jika informasi publik yang diperoleh akan menambah pengetahuan mereka namun responden kurang yakin jika informasi publik tersebut dapat membantu menambah penghasilan responden. Opini responden untuk keakuratan informasi publik dari petugas penyuluh pertanian kabupaten, kecamatan, dan ketua kelompok/rukun nelayan bernilai positif.
Opini responden untuk penilaian tentang akses informasi publik adalah positif, pada umumnya responden menilai petugas penyuluh perikanan kabupaten, kecamatan, dan ketua kelompok/rukun nelayan cukup menarik dalam memberikan informasi publik.

Opini responden untuk kecenderungan perilaku responden dalam mengakses informasi adalah netral dan positif.

\section{Saran}

Pemerintah dalam hal ini Kementerian Kaluatan dan Perikanan hendaknya lebih mengintensifkan para petugas penyuluh perikanan baik yang berada di Dinas Kelautan dan Perikanan Kabupaten maupun yang berada di kecamatan, agar nelayan lebih mudah dan lebih sering dalam mengakses informasi publik dan dijamin keakuratan informasinya.

Pemerintah daerah hendaknya juga mendorong dan memfasilitasi kelompokkelompok nelayan untuk mendirikan media komunitas seperti radio komunitas misalnya, agar aspirasi mereka bisa tersalurkan melalui media tersebut.

Kementerian Komunikasi dan Informatika khususnya Dirjen Aptika diharapkan bisa memberikan layanan internet sehat dan gratis dan juga perangkatnya di daerah nelayan, khususnya nelayan di Kabupaten Karawang, melakukan pendampingan pada masyarakat yang diberi layanan internet hingga mereka benar-benar bisa menggunakan internet dengan baik dan benar, serta memberikan bimtek training of trainne (TOT) tentang penggunaan internet dan cara mengakses informasi melalui internet kepada para petugas penyuluh perikanan agar mereka juga bisa memberikan pelatihan kepada masyarakat di daerah mereka.

Kementerian Komunikasi dan Informatika hendaknya juga membangun infrastruktur yang berkaitan dengan TIK serta membuat regulasi yang mendukung, secara merata di berbagai daerah khususnya di daerah nelayan Kabupaten Karawang untuk mengurangi kesenjangan digital. Kemudahan dalam mendapatkan informasi secara tidak 
langsung akan membantu pemerintah dalam meningkatkan kesejahteraan masyarakat.

\section{DAFTAR PUSTAKA}

\section{Buku:}

Devito, Joseph A.(1997). Komunikasi Antarmanusia.Jakarta:Professional Books.

Morissan.(2013).Teori Komunikasi Individu Hingga Massa.Jakarta: Kencana Prenada Media Group.

Nimmo, Dan.(2005).Komunikasi Politik,

Komunikator,

Media.Bandung:PT

Rosdakarya.

Rakhmat,

Jalaluddin.(2012).Metode

Penelitian Komunikasi.Bandung: PT

Remaja Rosdakarya.

$$
\text { ...(2012).Psikologi }
$$

Komunikasi.Bandung: PT Remaja

Rosdakarya.

Singarimbun, Masri.(1989).Metode Penelitian

Survey.Jakarta : PT Midas Surya Grafindo.

Sutanta, Edhy.(2003).Sistem Informasi Manajemen. Yogyakarta: Graha Ilmu.

West, Richard dan Lynn

H.Turner.(2013).Pengantar Teori

Komunikasi Analisis dan

Aplikasi.Jakarta: Salemba Humanika.

\section{Jurnal:}

Sipahelut,

Michel.(2010).Analisis

Pemberdayaan Masyarakat Nelayan Di

Kecamatan Tobelo Kabupaten

Halmahera Utara.Tersedia dalam

$<$ mfile.narotama.ac.id/files/umum/jurna

1 IPB/Analisis Pemberdayaan

Masyarakat Nelayan di Kecamatan

Tobelo Kabupaten Halmahera Utara>, diakses tanggal 2 Februari 2015.

Sugiharto, dkk.(2008).Kajian Karakteristik

Nelayan Terhadap Akses Sumber
Informasi (Studi Kasus di Desa Parangtritis, Kecamatan Kretek, Kabupaten Bantul Yogyakarta). Jurnal Komunikasi Pembangunan. Volume 06. No.1, Februari 2008, 31.

\section{Tesis:}

Sitorus, Sri Wahyuni. (2013), Analisis Keberlanjutan Budidaya Udang Vaname (Litopenaeus vannamei) dalam Pengembangan Kawasan MInapolitan di Beberapa Desa Kecamatan Pantai Cermin Kabupaten Serdang Bedagai Provinsi Sumatera Utara. Semarang: Program pasca Sarjana UNDIP.

\section{Internet:}

Astuti.(2012).Pemahaman Akses Dalam Kearsipan.Tersedia dalam www.bpadjogja.info/file/47691ac2069. pdf. Diakses tanggal 5 Maret 2015.

Prabadipta, Herda.(2013).Keterbukaan Informasi Publik di Jawa Timur (Studi Kasus Sengketa Informasi Publik).Tersedia dalam https://www.academia.edu/3483272

Rahajeng, Ria.(2010). Pola Penggunaan Televisi di Kalangan Nelayan (Studi Kasus di Kelurahan Kutawaru, Kecamatan Cilacap Tengah, Kabupaten Cilacap, Jawa Tengah)Tersedia dalam http://digilib.uns.ac.id/abstrak_17767_p ola-penggunaan-televisi-di-kalangannelayan--studi-kasus-tentang-polapenggunaan-televisi-di-kalangannelayan-di-kelurahan-kutawaru,kecamatan-cilacap-tengah,-kabupatencilacap,-jawa-tengah-.html. Diakses tanggal 10 Februari 2015.

Sutisna, Dedy Heryadi.(2012). Potensi Ekonomi Kelautan Mampu Menyejahterakan Rakyat Indonesia. Tersedia dalam http://www.dekin.kkp.go.id/?q=news\&i $\mathrm{d}=201208021009083559747685524338$ 25750659740299, diakses tanggal 29 Januari 2014 pukul 10.25WIB. 